\title{
Solar and Wind Energy Based Microgrid : Study of Architecture's Potential at Coastal Areas in Bangladesh
}

\author{
Abir Muhtadi, Ahmed Mortuza Saleque and Mohammad Abdul Mannan
}

\begin{abstract}
Due to sheer dependency upon fossil fuel sources, Bangladesh as a country is not free from numerous negative aspects. Country's requirement for a certain portion of power be generated from renewable energy sources is due and required renewable energy target (RET) needs to be fulfilled. In this study, potential of distinguished coastal sites for entirely renewable energy such as solar and wind sources based microgrid for chosen community is explored. Microgrid architecture is appropriate considering the coastal areas' geographical locations and due to the inconvenience in grid extension. Study suggests, potential of coastal sites are found to be feasible for such structures based on real case scenario data and modelled technical scheme.
\end{abstract}

Keywords- Renewable Energy, Microgrid, Coastal Areas, Hybrid Energy System, Green House gases

\section{INTRODUCTION}

Energy consumption is thought to be one of significant contributors to environmental pollution because of degradation of fossil fuel resources, emission of harmful Green House Gases and so on. Annual energy consumption will be doubled by the year of 2050 if the present rate of population growth is retained [1]. Due to factors as such, a significant percentage of power generation means are gradually involving renewable or clean energy sources such as solar, wind, tidal etc. Distributed energy resources conducive electrical power generation structure like 'Microgrid' could impact with the most in terms of clean power sources' integration and remote region electrification where grid integration isn't feasible or possible due to geographical reasons.

Microgrid could be defined as a small scaled power generation

Abir Muhtadi

American International University-Bangladesh

Dhaka, Bangladesh

abir.muhtadi@northsouth.edu

Ahmed Mortuza Saleque

American International University-Bangladesh

Dhaka, Bangladesh

ahmed.saikot@gmail.com

Mohammad Abdul Mannan

American International University-Bangladesh

Dhaka, Bangladesh

mdmannan@aiub.edu architecture which could employ various energy sources (conventional/renewable), storages and different devices to provide power of grid quality during both standalone or connected with grid mode [2].

A solar and small scale wind energy farm based hybrid power generation is suggested in [3] to mitigate major fluctuation between peak and medium load level in a diesel power driven medium scale grid. An increment of power generation efficiency has been focus of discussion in [4] considering mix of solar, wind, conventional sources and storages along with combined heat and power systems. The discussion offers microgrid as a mean of operation and management for all the distributed energy resources. A financially more viable microgrid scheme is proposed in [5] where it is observed that hybrid renewable energy sources based microgrid turns out to be more feasible economically than sole kind of source based scheme based on real case scenario data at different locations in Hong Kong.

In this research work, the aim is to have a complete study of opportunities of hybrid microgrid scheme (solar PV \& Wind) for the sake of distant area electrification in major coastal areas in Bangladesh. As per study conducted in [6] regarding renewable energy potential at coastal areas in Bangladesh, focusing in wind energy prominently - the five distinguished coastal sites (Char Fasson, Chittagong, Kuakata, Kutubdia \& St. Martin's) are selected. The coastal areas are chosen for experimentation under technical scheme discussed in [7] and a comparative study is conducted based on their power output measurement for a similar community as chosen in the reference.

\section{AVAILABLE RENEWABLE ENERGY} RESOURCES AT CHOSEN COASTAL AREAS

The analysis is conducted on 12-month long period where average solar irradiance, temperature and average wind speed of the five coastal areas considered. The average monthly solar irradiance, temperature $\&$ average monthly wind speed at the sites are collected from NASA's "Surface Meteorology and Solar Energy" website [8] and [6], respectively. The detailed analysis (recorded data, solar PV \& wind farm simulation) of St. Martin's Island is conducted in [7] and output forms are later extracted for comparative analysis with rest of the four sites. 
III. TECHNICAL MODEL AND SIMULATED POWER OUTPUT AT COASTAL AREAS
The microgrid modelled and simulated in [7] incorporates solar PV farm which includes "Perturb and Observe (P \& O)

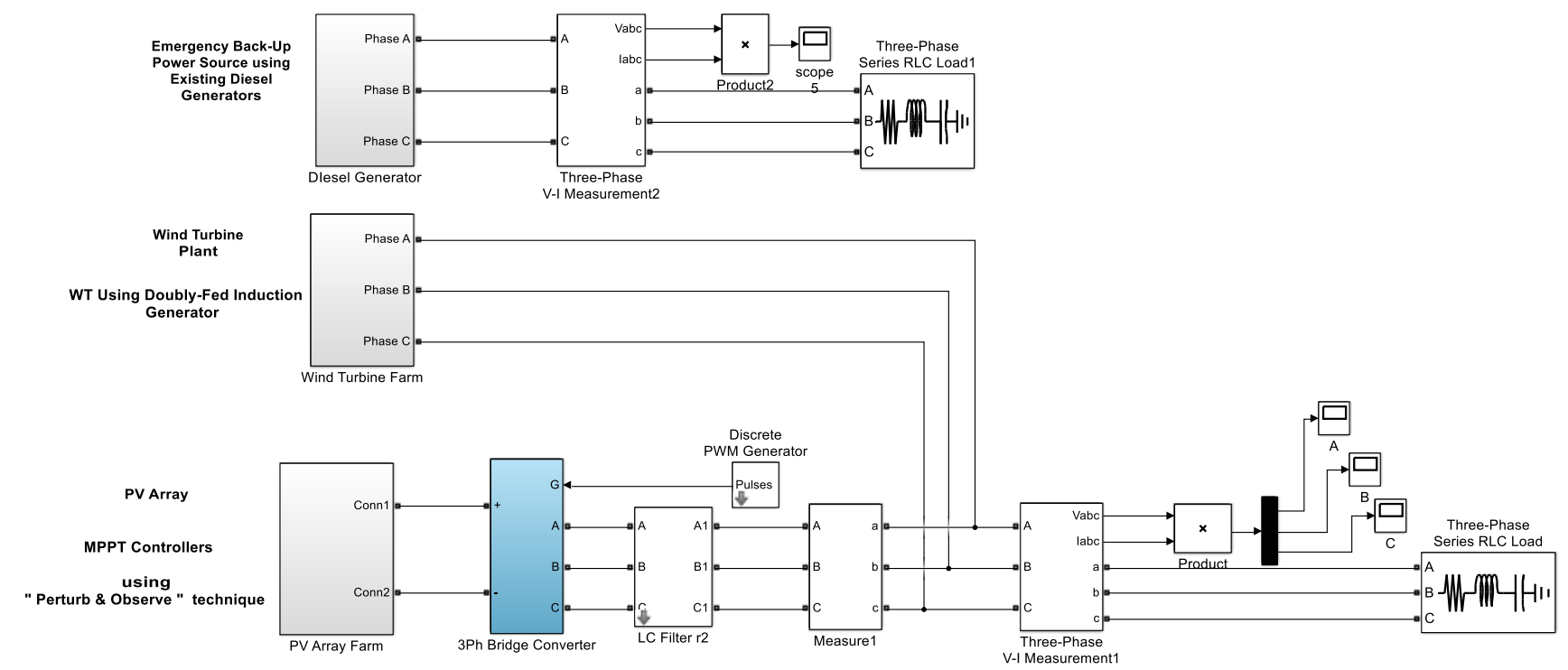

Fig. 1 Simulation of Microgrid Consisting Solar PV, DFIG based Wind Energy Conversion System and Backup Diesel Generator [7]

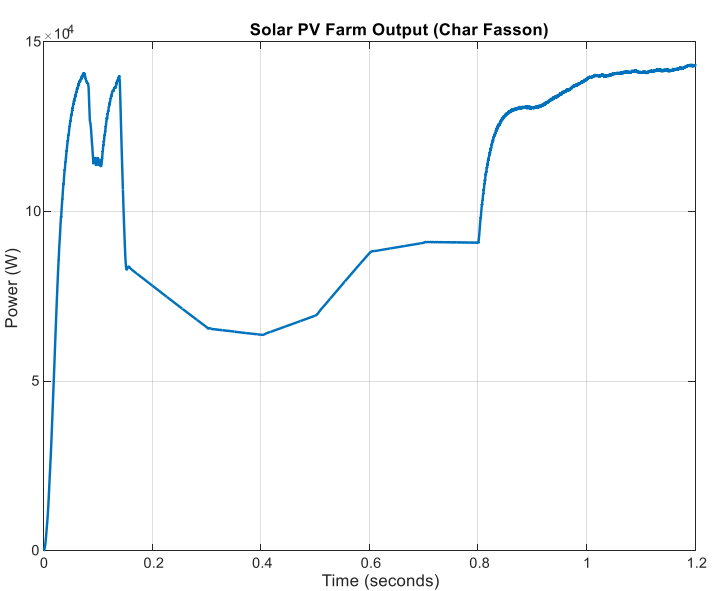

(a)

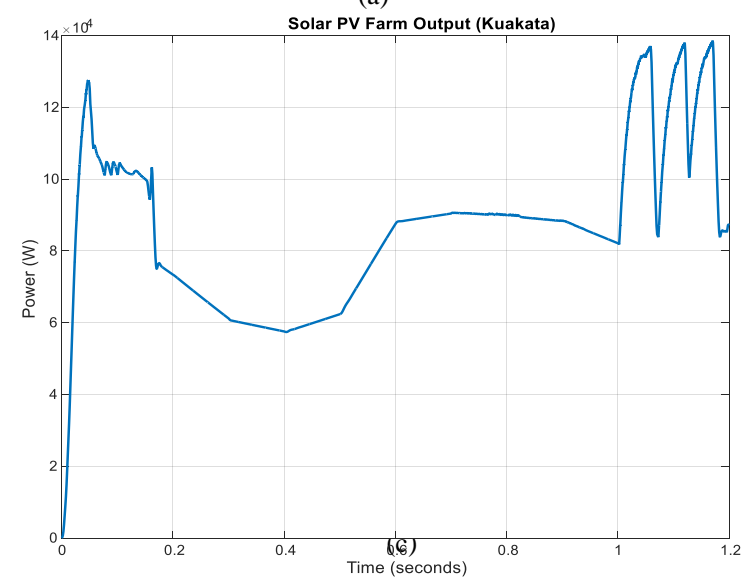

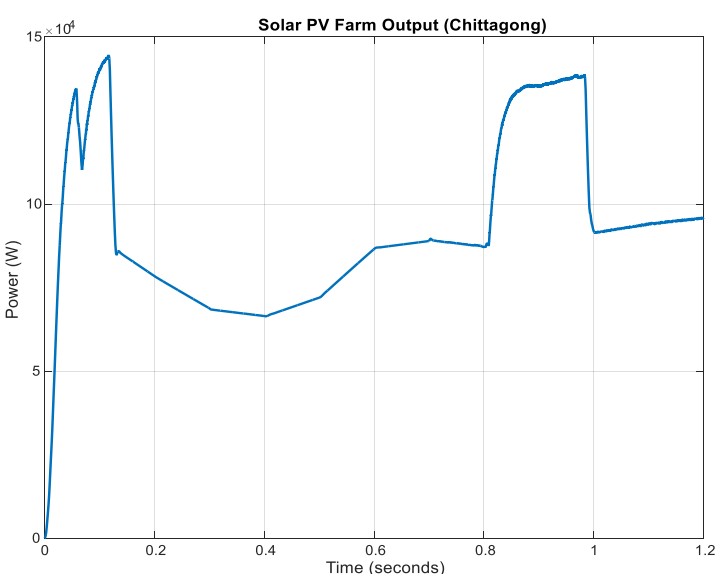

(b)

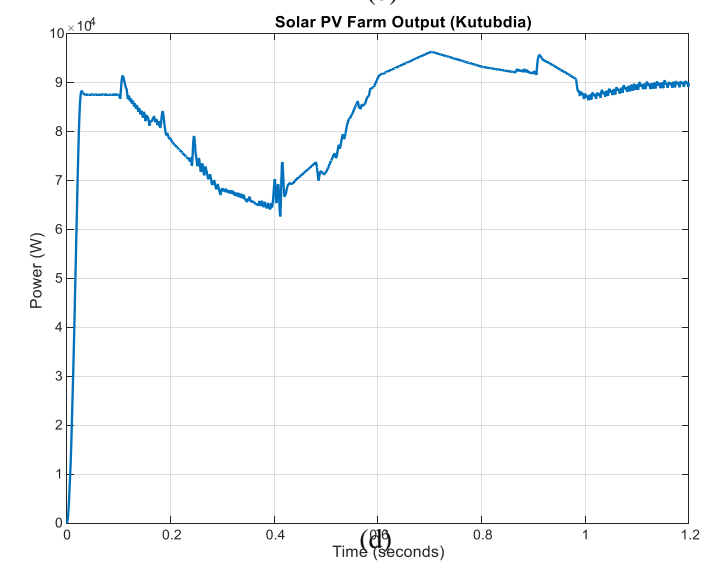




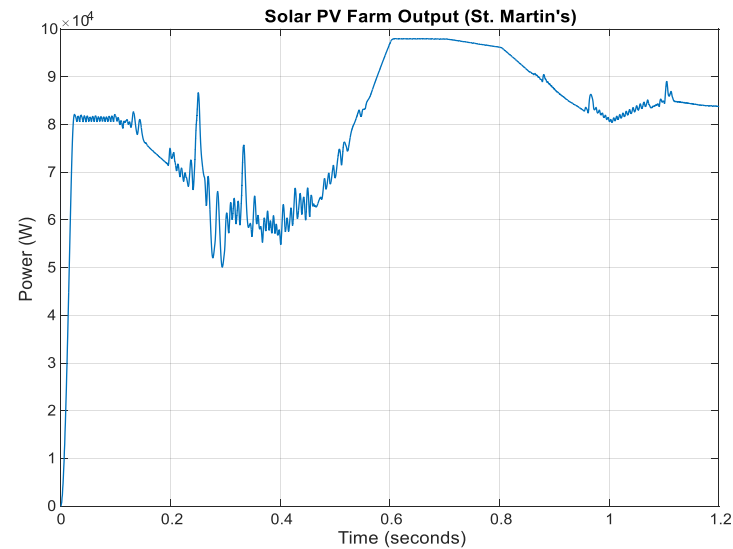

(e)

Fig. 2: Solar PV Farm Outputs at Coastal Areas (a) Char Fasson (b) Chittagong (c) Kuakata (d) Kutubdia (e) St. Martin’s
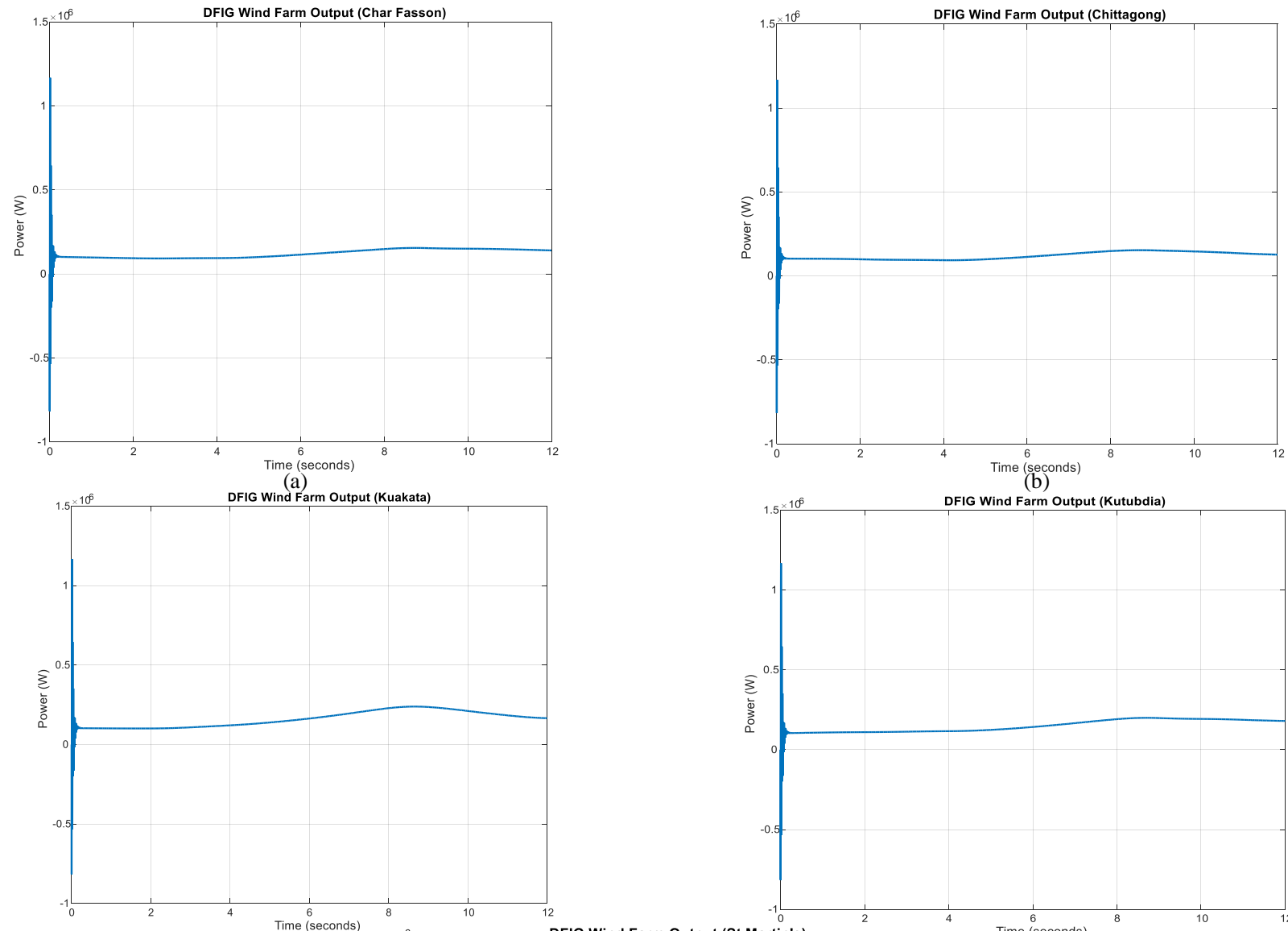

(c)

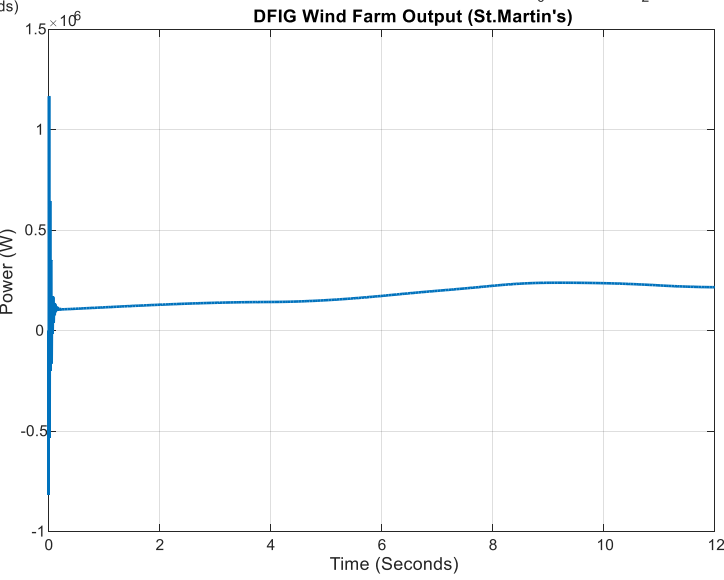

(d)

(e)

Fig. 3: DFIG Wind Farm Real Power Output (W) at Coastal Areas (a) Char Fasson (b) Chittagong (c) Kuakata (d) Kutubdia (e) St. Martin's 
Algorithm for "Maximum Power Point Tracking (MPPT)". The entirely renewable energy sources based microgrid consisting wind and solar energy is designed to cater for electrical load demand $(17 \mathrm{kWh}$ peak load over 12 -month period) of a sample population at St. Martin's Island. The detailed specification and modelling of solar PV system is discussed in the reference paper [7]. Similarly, following the performance study analysis between two kinds of WECS in [9], DFIG is chosen for WECS \& integrated in microgrid structure. For power generation capacity performance study of entirely renewable energy dependent microgrid which includes solar PV and DFIG based WECS at four coastal areas (five including St. Martin's) where data are recorded for similar load consumption of chosen sample population as in [7]. The two kinds (solar PV and DFIG based WECS) of generation models deployed in entirely renewable energy based microgrid's technical scheme constructed in [7] are run for simulation to unveil the power generation capacity at the chosen sites based on the acquired resource dataset. Solar and wind farms' combined output forms are analyzed in terms of feasibility as whether similar microgrid structure is capable of serving such load requirement or it is the otherwise.

\section{COMPARATIVE ANALYSIS AMONG COASTAL AREAS BASED ON OUTPUT}

The Assessment of the power output forms of solar PV farms at the coastal areas do draw interesting results. Here in the simulated outputs, the $\mathrm{x}$-axis represents "Months" while twelve months ranging from 0.1 to 1.2 seconds on equal distribution, each value representing a month.

In the simulated output form of solar PV farm with solar irradiance and temperature data recorded at Char Fasson, it is seen to have produced least output at 0.4 second which represents the month of April (4th month of the year). The solar farm produced output on April is around $63 \mathrm{~kW}$ while the maximum output achieved is approximately $140 \mathrm{~kW}$ during the month of December, represented by point 1.2 seconds.

In case of second coastal area chosen, Chittagong; it is seen that the least power generated by the solar PV farm is around $65 \mathrm{~kW}$ during 0.4 second which representing the month of April. The peak power produced is during 0.1 second representing the month of January. The third coastal area chosen for simulation analysis is Kuakata situated in Barisal division and by the coast of Bay of Bengal - the least power generated in this region by the means of solar PV farm is around $59 \mathrm{~kW}$ during April represented by simulation period of 0.4 second whereas the maximum power output $128 \mathrm{~kW}$ generated is during November represented by 1.1 seconds. The fourth and fifth coastal areas picked up for analysis are Kutubdia and St. Martin's, give least microgrid power output of $64 \mathrm{~kW}$ at around simulation period of 0.4 second representing April and $50 \mathrm{~kW}$ at around 0.3 second representing March respectively, whereas for maximum power output it is noticed that, at site of Kutubdia, the solar PV farm generated peak power output is around $96 \mathrm{KW}$ during 0.7 second representing July and in case of St. Martin's the maximum power generated is almost $98 \mathrm{~kW}$ during 0.6 second which is representing the month of June.

Table I: Power Generated in Solar PV Farms at Coastal Areas

\begin{tabular}{|c|c|c|c|c|c|}
\hline \multirow{2}{*}{$\begin{array}{c}\text { Power }(\mathbf{k W}) \\
\text { on Month } \\
\text { Basis }\end{array}$} & \multicolumn{5}{|c|}{ Coastal Sites } \\
\hline & $\begin{array}{c}\text { Char } \\
\text { Fasson }\end{array}$ & $\begin{array}{l}\text { Chitta- } \\
\text {-gong }\end{array}$ & Kuakata & $\begin{array}{c}\text { Kutu } \\
\text { bdia }\end{array}$ & $\begin{array}{c}\text { St. } \\
\text { Martin's }\end{array}$ \\
\hline $\begin{array}{l}\text { January } \\
(0.1 \mathrm{sec})\end{array}$ & 112 & 132 & 101 & 87 & 81 \\
\hline $\begin{array}{l}\text { February } \\
(0.2 \mathrm{Sec})\end{array}$ & 78 & 80 & 72 & 78 & 72 \\
\hline $\begin{array}{c}\text { March } \\
(0.3 \mathrm{sec})\end{array}$ & 67 & 68 & 60 & 67 & 65 \\
\hline $\begin{array}{c}\text { April } \\
(0.4 \mathrm{sec})\end{array}$ & 63 & 65 & 59 & 70 & 57 \\
\hline $\begin{array}{c}\text { May } \\
(0.5 \mathrm{sec})\end{array}$ & 68 & 68 & 61 & 72 & 70 \\
\hline $\begin{array}{c}\text { June } \\
(0.6 \mathrm{sec})\end{array}$ & 85 & 83 & 88 & 91.5 & 97.5 \\
\hline $\begin{array}{c}\text { July } \\
(0.7 \mathrm{sec}) \\
\end{array}$ & 90 & 85 & 90 & 96.5 & 96 \\
\hline $\begin{array}{c}\text { August } \\
(0.8 \mathrm{sec})\end{array}$ & 88 & 83 & 89 & 93 & 95.5 \\
\hline $\begin{array}{c}\text { September } \\
(0.9 \mathrm{sec})\end{array}$ & 130 & 135 & 87 & 92 & 85 \\
\hline $\begin{array}{l}\text { October } \\
(1.0 \mathrm{sec}) \\
\end{array}$ & 137 & 92 & 80.9 & 88 & 81 \\
\hline $\begin{array}{c}\text { November } \\
(1.1 \mathrm{sec})\end{array}$ & 138 & 93 & 128 & 90 & 84 \\
\hline $\begin{array}{c}\text { December } \\
(1.2 \mathrm{sec})\end{array}$ & 140 & 94 & 83 & 89 & 83 \\
\hline
\end{tabular}

From the Table I above it is noticed among the microgrid sites, the least power is generated during the month of MarchApril and maximum power outputs are produced during November-January or June-July. In terms of microgrid output characteristics at these coastal sites - similarity is observed throughout the year except for month of September when a rise in power output of the solar PV farms is observed at Char Fasson and Chittagong whereas a decrement in simulated output is obtained at Kuakata, Kutubdia \& St. Martin's. Overall congruence obtained in solar PV farm power output forms extracted at these coastal sites prove that the chosen coastal areas are viable for similar microgrid configuration which employs solar PV farm as in [7] for the typical community chosen.

In case of DFIG WECS power output forms at the coastal sites obtained exhibit that encountered fluctuation in active power output is almost negligible and remains similar throughout the year at the chosen sites. The produced active power at the sites are almost at similar range while keeping a sheer consistency in generation. The detailed active power generation at the coastal sites are tabulated - 
Table II: Power Generated in DFIG WECS Farms at Coastal Areas

\begin{tabular}{|c|c|c|c|c|c|}
\hline $\begin{array}{c}\text { Power (kW) } \\
\text { on Month } \\
\text { Basis }\end{array}$ & $\begin{array}{c}\text { Char } \\
\text { Fasson }\end{array}$ & $\begin{array}{c}\text { Chitta- } \\
\text {-gong }\end{array}$ & Kuakata & $\begin{array}{c}\text { Kutub } \\
\text { dia }\end{array}$ & $\begin{array}{c}\text { St. } \\
\text { Martin's }\end{array}$ \\
\hline $\begin{array}{c}\text { January } \\
(0.1 \text { sec) }\end{array}$ & 90 & 105 & 113 & 110 & 108 \\
\hline $\begin{array}{c}\text { February } \\
(0.2 \text { Sec) }\end{array}$ & 85 & 100 & 111 & 111 & 110 \\
\hline $\begin{array}{c}\text { March } \\
(0.3 \mathrm{sec})\end{array}$ & 82 & 97 & 114 & 112 & 112 \\
\hline $\begin{array}{c}\text { April } \\
(0.4 \mathrm{sec})\end{array}$ & 84 & 96 & 116 & 111 & 110 \\
\hline $\begin{array}{c}\text { May } \\
(0.5 \mathrm{sec})\end{array}$ & 89 & 99 & 117 & 113 & 112 \\
\hline $\begin{array}{c}\text { June } \\
(0.6 \mathrm{sec})\end{array}$ & 104 & 108 & 118 & 115 & 115 \\
\hline $\begin{array}{c}\text { July } \\
(0.7 \mathrm{sec})\end{array}$ & 108 & 110 & 119 & 117 & 117 \\
\hline $\begin{array}{c}\text { August } \\
(0.8 \mathrm{sec})\end{array}$ & 112 & 115 & 121 & 120 & 118 \\
\hline $\begin{array}{c}\text { September } \\
(0.9 \mathrm{sec})\end{array}$ & 111 & 112 & 120 & 119 & 121 \\
\hline $\begin{array}{c}\text { October } \\
(1.0 \mathrm{sec})\end{array}$ & 110 & 109 & 117 & 118 & 120 \\
\hline $\begin{array}{c}\text { November } \\
(1.1 \mathrm{sec})\end{array}$ & 108 & 107 & 115 & 117 & 118 \\
\hline $\begin{array}{c}\text { December } \\
(1.2 \mathrm{sec})\end{array}$ & 106 & 105 & 114 & 116 & 117 \\
\hline
\end{tabular}

The fluctuation in power output from the DFIG based WECS at the coastal sites can be understood from the tabulated values in Table II. The variation in power output is very minimal among the microgrid configuration at coastal sites - not more than $5 \mathrm{KW}$ over the 12-month period except for one instance, during transition from month of May to June in case of Chittagong. The fluctuation is a rise of $9 \mathrm{KW}$ in power output during the transition. So even from the employment of WECS perspective, the microgrid configuration seems to be quite feasible at the chosen coastal areas to generate power for a typical community considered in [7].

\section{CONCLUSION}

In Bangladesh, the majority of generated energy comes from fossil fuel sources which is causing the environment serious harm. The study conducted brings about a comparative analysis of solar and wind energy based microgrid's potential at prominent coastal areas. Entirely renewable energy sources based microgrid structure modelled in [7] is exposed to realistic dataset of sources at prominent coastal areas to inspect feasibility of the architecture in terms of power generation capability to meet chosen community's peak load demand of $17 \mathrm{kWh}$ over 12-month duration. Entirely renewable energy based microgrid scheme has employed small portion of diesel generator blessed power generation for minimum load demand fulfillment while it is unfavorable to generate power from renewable energy sources. Overall, the coastal sites are found to be feasibly potential for entirely renewable energy based microgrid in terms of power generation capacity to meet up specified load demand which could lead to country's requirement of renewable energy target (RET) fulfillment and reduced level of environmental pollution.

\section{REFERENCES}

[1] A. Harrouz, M. Abbes, I. Colak, K. Kayisli, "Smart Grid and Renewable Energy in Algeria", IEEE 6th International Conference on Renewable Energy Research and Applications (ICRERA), pp. 1167-1171, November 5-8, 2017.

[2] Nayar, Chem. "Innovative Remote Micro-Grid Systems", International Journal of Environment and Sustainability, ISSN 1927-9566 | Vol. 1 No. 3, pp. 53-65 (2012).

[3] C. Nayar, "Remote Area Micro-Grid System using Diesel Driven Doubly Fed Induction Generators Photovoltaics and Wind Generators", IEEE International Conferences on Sustainable Energy Technologies, pp. 1081-1086, November 24-27, 2008.

[4] B. Lasseter, "Microgrids (distributed power generation)", IEEE Power Engineering Society Winter Meeting, vol. 01, pp. 146-149, Feb 2001.

[5] H. Wang, J. Huang, "Hybrid Renewable Energy Investment in Microgrid", Proc. IEEE Smart Grid Comm, pp. 602-607, 2014.

[6] S K Khadem, L Mariam, H R Ghosh, J Rahman, "Feasibility study of wind home system in coastal region of Bangladesh", Dhaka Univ. J. Sci., 2007, v-55(2), p: 263-268.

[7] A. Muhtadi, A.M. Saleque, "Modeling and Simulation of a Microgrid consisting Solar PV \& DFIG based Wind Energy Conversion System for St.Martin's Island", in 3rd International Conference on Engineering Technologies \& Social Sciences (ICETSS), 7-8th August, 2017

[8] "NASA Surface Meteorology and Solar Energy website", available at: https://eosweb.larc.nasa.gov/cgibin/sse/grid.cgi?email=skip\%40larc.nasa .gov\&step=1\&lat=20.623702\&lon=92.323395\&submit=Submit, accessed on December 2017

[9] A. Muhtadi, A.M. Saleque, "A Performance Study based on Comparative Analysis between SCIG and DFIG based Wind Energy Conversion System in a Microgrid at St.Martin's Island", in 4th International Conference on Advances in Electrical Engineering (ICAEE), 28-30th September, 2017

[10] S. Zhang and M. Huang, "Microgrid: A Strategy to Develop Distributed Renewable Energy Resource", in International Conference on Electrical and Control Engineering (ICECE), pp. 3520-3523, Sept. 2011.

[11] Farahat S., Jahromi M., Barakati S.M., "Modeling and Sizing Optimization of Standalone Hybrid Renewable Energy Systems" in International Conference on Mechanical, Nanotechnology and Cryogenics Engineering (ICMNC'12), 25-26th August, 2012.

[12] F. Katiraei, M. R. Iravani, P. W. Lehn, "Small Signal Dynamic Model of a Microgrid including Conventional and Electronically Interfaced Distributed Sources", IET Generation Transmission and Distribution, vol. 1, 2007.

[13] S. Kumaravel, S. Ashok and P. Balamurugan, "Techno-Economic Feasibility Study of Biomass based Hybrid Renewable Energy Eystem for Microgrid Application", International Conference on Green Technologies (ICGT), 2012.

[14] G. Wu, S. Kodama, Y. Ono, Y. Monma, "A Hybrid Microgrid System including Renewable Power Generations and Energy Storages for Supplying both the DC and AC Loads", International Conference on Renewable Energy Research and Applications (ICRERA), pp. 1-5, 1114th Nov. 2012.

[15] Islam, A., Rahman, M., Mondal, M. and Alam, F. "Hybrid energy system for St. Martin Island, Bangladesh: An optimized model”, Procedia Engineering, 49, pp.179-188, 2012.

[16] R. K. Pachauri, K. Chauhan, 'Assessment of Wind Energy Technology Potential in Indian Context', International Journal of Renewable Energy Research-IJRER, Vol 2, No 4, 2016.

[17] H. F. Abarghouei, S. Hasanvand, S. Sahraneshin, "Distributed Generation Planning \& Grid Partitioning for Voltage Control of Smart Distribution System", International Journal of Renewable Energy Research-IJRER, Vol 6, No 4 (2016). 
[18] V. O. Okinda, N. A. Odero, "Modeling, Simulation and Optimal Sizing of a Hybrid Wind, Solar PV Power System in Northern Kenya", International Journal of Renewable Energy Research-IJRER, Vol 6, No 4, 2016.

[19] A. UPPAL, Dr JP Kesari, "Designing of Solar Process Heating System for Indian Automobile Industry", International Journal of Renewable Energy Research-IJRER, Vol 6, No 4, 2016.

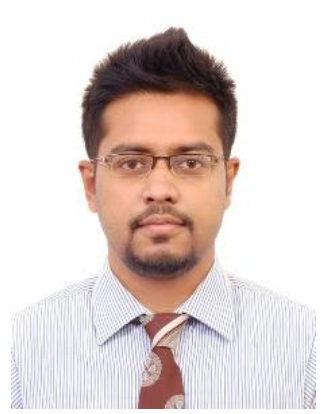

Abir Muhtadi was born in Dhaka, Bangladesh on $8^{\text {th }}$ November 1992. He received his BSc. In EEE Degree from North South

University, Bangladesh in 2014 and MSc. In EEE Degree from American International University-Bangladesh in 2017 being among top $1 \%$ of the class. His research interests include Renewable Eenergy Integration, Smart Grid, Microgrid.

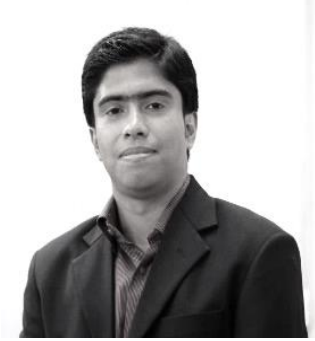

Ahmed Mortuza Saleque was born in Bogra, Bangladesh in 1989. He received

Bachelor Degree in Electrical and Electronic Engineering from American International University, Bangladesh in 2010. In the same year he joined the Department of Electrical and Electronic Engineering, American International University-Bangladesh (AIUB) as Lecturer. He received Master of Engineering in Telecommunications from American International
University-Bangladesh in 2012. Both in his Bachelor and Master's, he received the prestigious Summa Cum Laude distinction.

From 2013 to 2015, he was awarded Erasmus Mundus scholarship for Master's program. He received joint Master degree in Sustainable Transportation and Electrical Power Systems (EMMC-STEPS) from University of Wisconsin Madison, USA, University of Nottingham, UK, University of Oviedo, Spain and University of Rome, Italy.

He was Visiting Scholar at the Wisconsin Electric Machines and Power Electronics Consortium (WEMPEC), University of Wisconsin-Madison, USA, in 2015. His research interests include Electric Drives, Deadbeat Direct Torque and Field Oriented Control (DB-DTFC), Power Electronics, Electric and Hybrid Vehicle Technology, Digital Control and Signal Processing.

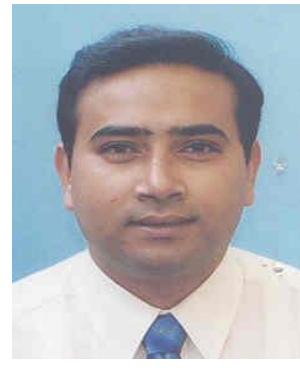

Mohammad Abdul Mannan was born in Laxmipur, Bangladesh on January 01, 1975. $\mathrm{He}$ received his B. Sc. Eng. Degree from Rajshahi University of Engineering and Technology (RUET former BITR), Bangladesh, in 1998, and Masters of Eng. and Dr. of Eng. degrees from Kitami Institute of Technology, Japan, in 2003 and 2006 respectively, all in electrical engineering. He then joined in the American International University Bangladesh (AIUB) as an Assistant professor on May 2006. Currently he is serving as Professor and Head (Undergraduate Program), EEE Dept. in AIUB. His research interests include electric motor drive, power electronics, power system, wind generation system and control of electric motor, power electronic converters, power system, and wind generation system. 